\title{
Pertumbuhan Tanaman Sengon (paraserianthes falcataria L.) Terinfeksi Mikoriza pada Lahan Tercemar Pb.
}

\author{
Triono Bagus Saputro ${ }^{1}$, Nurul Alfiyah ${ }^{2}$, Dian Fitriani ${ }^{3}$ \\ Jurusan Biologi, Fakultas Matematika dan Ilmu Pengetahuan Alam, \\ Institut Teknologi Sepuluh Nopember (ITS) \\ Sukolilo, Surabaya 60111 Indonesia \\ e-mail: trionobsaputro@bio.its.ac.id
}

\begin{abstract}
Paraserianthes falcataria plant is well known to be capable to make an excellent association and symbiosis with mycorrhizae. Mycorrhizae can improve the plant's ability to survive in heavy metal contaminated land, one of which is $\mathrm{Pb}$ (lead). $\mathrm{Pb}$ is the main heavy metal pollutants in all environments. This aims of this research were to determine the accumulation of $\mathrm{Pb}$ on sengon plant roots and its growth in Pb contaminated media. This research uses a completely randomized design. $\mathrm{Pb}\left(\mathrm{NO}_{3}\right)_{2}$ were given at a dose of $833 \mathrm{mg} / \mathrm{kg}$ and the concentration of mycorrhizal inoculation of Glomus sp. used were 25, 50 and 75 grams of mycorrhizae. The measured parameters were plant height, root length, plant dry weight, accumulation of $\mathrm{Pb}$ in roots, chlorophyll and protein profile test. The results showed that 75 grams of mycorrhizal Glomus sp. were the highest on several parameters including plant height, dry weight, root length. The chlorophyll content were grown on media containing Pb with each value of $77.5 \mathrm{~cm} ; 17.86$ grams; $31.5 \mathrm{~cm} ; 8.99 \mathrm{~g} / \mathrm{ml}$. A dose of 75 grams of Glomus sp. also increased the absorption and accumulation of $P b$ in the roots with $3.60 \mathrm{ppm}$. while the protein electrophoresis show the specific band in P. falcataria that exposed to $\mathrm{Pb}$ with molecular weight $53.67 \mathrm{kDa}$.
\end{abstract}

Keywords : Paraserianthes falcataria L.; Metal Pb; Glomus sp.

\begin{abstract}
Abstrak
Tanaman Paraserianthes falcataria L. diketahui mampu berasosiasi dan bersimbiosis dengan mikoriza, dimana peran mikoriza dapat meningkatkan kemampuan tanaman $P$. falcataria L. dalam bertahan di lahan tercemar logam berat, salah satunya adalah $\mathrm{Pb}$. Logam berat $\mathrm{Pb}$ merupakan pencemar logam berat utama di semua lingkungan. Penelitian ini bertujuan untuk mengetahui akumulasi logam $\mathrm{Pb}$ pada perakaran tanaman sengon serta pertumbuhannya dalam media tercemar logam berat $\mathrm{Pb}$. Penelitian ini menggunakan rancangan acak lengkap. Pemberian logam berat $\mathrm{Pb}\left(\mathrm{NO}_{3}\right)_{2}$ dengan dosis $833 \mathrm{mg} / \mathrm{kg}$ dan konsentrasi inokulasi mikoriza Glomus sp. yang digunakan adalah 25, 50 dan 75 gram mikoriza. Parameter yang diamati adalah tinggi tanaman, panjang akar, berat kering tanaman, akumulasi $\mathrm{Pb}$ dalam akar, kandungan klorofil dan uji profil protein. Hasil dari penelitian ini yaitu dosis 75 gram mikoriza Glomus sp. merupakan dosis yang paling berpengaruh terhadap pertumbuhan tanaman sengon pada parameter tinggi tanaman, berat kering, panjang akar dan kandungan klorofil yang ditumbuhkan pada media yang mengandung logam $\mathrm{Pb}$ dengan masing-masing nilai 77,5 cm; 17,86 gram; 31,5 cm; 8,99 g/ml. Dosis 75 gram Glomus sp. juga meningkatkan penyerapan serta akumulasi logam $\mathrm{Pb}$ pada akar tanaman sengon sebesar 3,60 ppm.

Kata kunci : Paraserianthes falcataria L.; Logam Pb;Glomus sp.
\end{abstract}

\section{Pendahuluan}

Sengon atau Paraserianthes falcataria

(L.) termasuk famili Leguminoceae. Tanaman

ini sangat potensial untuk dipilih sebagai salah satu komoditas dalam pembangunan hutan tanaman, karena memiliki nilai ekonomis tinggi dan ekologis yang luas. Keunggulan ekonomi Pohon Sengon adalah jenis pohon 
kayu cepat tumbuh (fast growing species), pengelolaan relatif mudah, sifat kayunya termasuk kelas kuat dan permintaan pasar yang terus meningkat (Nugroho dan Salamah, 2015), sedangkan secara ekologis Sengon dapat meningkatkan kualitas lingkungan seperti meningkatkan kesuburan tanah dan memperbaiki tata air (Suharti, 2008).

Timbal $(\mathrm{Pb})$ merupakan salah satu polutan utama di darat maupun di perairan. Limbah atau kotoran yang mengandung sejumlah timbal $(\mathrm{Pb})$ secara teratur dibuang ke kebun atau lahan yang biasa digunakan sebagai kegiatan pertanian (Paivoke, 2002). Peningkatan $\mathrm{Pb}$ dalam tanah dapat berdampak negatif terhadap penurunan pertumbuhan, produktivitas, hingga dapat menyebabkan kematian pada tanaman. Cunningham and Berti (1993) menyatakan bahwa logam $\mathrm{Pb}$ termasuk pencemar utama di semua lingkungan dan sumber utama pencemaran tanah karena memiliki distribusi/penyebaran yang luas serta mempunyai kelarutan yang rendah sehingga cenderung terakumulasi dan tersedimentasi dalam tanah.

Salah satu pilihan untuk mengatasi masalah pencemaran logam berat $\mathrm{Pb}$ dalam tanah adalah dengan proses fitoremediasi. Fitoremediasi merupakan proses pembersihan polusi maupun kontaminan di lingkungan dengan menggunakan tanaman (Etim, 2012). Akar tanaman yang berada ditanah dapat memainkan peran penting dalam meremoval logam melalui filtrasi, adsorbsi dan pertukaran ion, selain itu akar tanaman juga dapat menginduksi perubahan kimia di rhizosfer (Nouri et al., 2009). Usaha bioremediasi dapat dipercepat dengan tanaman bermikoriza, karena mikoriza menyediakan lingkungan yang optimal sehingga bibit tanaman dapat tumbuh dan memainkan perannya secara optimal (Widyati, 2008).

Selain itu juga mikoriza membantu meningkatkan penyerapan logam berat tanpa tanaman menderita keracunan yaitu dengan meningkatkan bioavailabilitas dan menurunkan toksisitas logam berat di tanah dengan melepaskan asam organik seperti asam oksalat (Sergio et al., 2012), Sehingga dalam penelitian ini sangat penting untuk mengetahui potensi tanaman sengon yang terinfeksi mikoriza arbuskular dalam mengakumulasi logam berat $\mathrm{Pb}$ serta pertumbuhan tanaman sengon yang terkontaminasi logam berat.

\section{Materi dan Metode}

Penelitian ini dilakukan pada bulan Februari 2015 sampai dengan Juli 2015 di Greenhouse Urban Farming ITS Surabaya dan laboratorium Botani Jurusan Biologi FMIPA ITS. Bahan yang digunakan pada penelitian ini adalah tanaman sengon (Paraserianthes falcataria L.), mikoriza Glomus sp., $\mathrm{Pb}\left(\mathrm{NO}_{3}\right)_{2}$.

\section{Sterilisasi Media Tanam}

Media yang digunakan adalah tanah taman yang disterilisasi dengan autoklaf 
selama 15 menit dengan tekanan 1 atm di laboratorium Botani Jurusan Biologi FMIPA ITS. Kemudian media tanam dianalisis sifat fisik ( $\mathrm{pH}$ tanah) dan kimia tanah (C-organik, NPK, kadar air) di Jurusan Tanah Fakultas Pertanian Universitas Brawijaya, Malang (Sastrahidayat, 2011).

\section{Penyiapan Tanaman}

Tanah yang sudah disterilkan sebanyak $3 \mathrm{~kg}$ dimasukkan pada setiap polybag. Bibit sengon umur 2 minggu dimasukkan dalam polybag yang berisi $3 \mathrm{~kg}$ media tanaman. Setiap polybag berisi 1 bibit sengon dan diinfeksi dengan spora Glomus sp. sebanyak 25 gram, 50 gram dan 75 gram. Kemudian dilakukan penyiraman setiap 1 kali sehari. Bibit sengon diadaptasi di lingkungan yang baru selama 2 minggu.

\section{Pembuatan Bioreaktor}

Media tanaman yaitu tanah taman dengan massa $3 \mathrm{~kg}$ dimasukkan ke dalam polybag dan diaduk sampai rata sambil ditambahkan logam berat $\mathrm{Pb}\left(\mathrm{NO}_{3}\right)_{2}$ dengan dosis $833 \mathrm{mg} / \mathrm{kg}$. Untuk penambahan mikoriza, tanaman sengon yang telah diadaptasi sebelumnya dan diinfeksi dengan spora Glomus sp. Dosis mikoriza yang diinokulasikan yaitu 25, 50 dan 75 gram mikoriza. Inokulasi mikoriza dilakukan dengan menggunakan sistem lapisan. Media tanam diambil dengan ketebalan $1 \mathrm{~cm}$, kemudian di atasnya dilapisi inokulum mikoriza dengan konsentrasi sesuai perlakuan kemudian dilapisi lagi dengan media tanam. Tanaman sengon kemudian dimasukkan ke dalam media. Tanaman diberi pupuk NPK sebanyak 3 gram (Hardiatmi, 2008), kemudian diukur $\mathrm{pH}$ tanah dengan alat soil tester dan selanjutnya ditumbuhkan pada rumah kaca selama 8 minggu. Disirami dengan air setiap hari sebanyak $100 \mathrm{cc}$.

\section{Pengairan dan Pengamatan}

Seluruh bioreaktor disirami dengan air sebanyak $250 \mathrm{ml}$ dalam $3 \mathrm{Kg}$ tanah setiap pengairan. Penyiraman tanaman dilakukan setiap hari sekali pada pukul 08.00 WIB. Adapun pengamatan yang dilakukan adalah mengukur tinggi tanaman, panjang akar, dan berat kering total.

\section{Analisis Hasil Uji Logam Pb}

Potensi tanaman sebagai remidiator dilakukan dengan menghitung akumulasi logam $\mathrm{Pb}$ dalam akar dengan menggunakan Atomic Absorption Spectrometry (AAS).

\section{Uji Kandungan Klorofil}

Ekstraksi klorofil mengacu pada metode Hiscox dan Israeslstam, dimana daun ditimbang dengan berat $0,5 \mathrm{~g}$ dan dihancurkan dengan menggunakan mortar dan pestel, selanjutnya diekstrak dengan larutan aseton 85\% $10 \mathrm{ml}$. Ekstrak yang diperoleh kemudian disaring dengan kertas saring dan dianalisis menggunakan spektrofotometer UV Vis pada 
panjang gelombang $644 \mathrm{~nm}$ dan $663 \mathrm{~nm}$. Penghitungan kandungan klorofil $(\mathrm{g} / \mathrm{ml})$ ditentukan dengan rumus :

Klorofil total $=8,02($ A.663 $)+20,2$ (644).W/V

\section{Keterangan : \\ W: Berat daun $(\mathrm{g})$ \\ $\mathrm{V}$ : Volume larutan aceton (ml)}

\section{Uji Profil Protein}

Metode isolasi protein mengacu pada penelitian (Saputro, 2012), yakni sebagai berikut: daun tanaman sengon ditimbang sebanyak $200 \mathrm{mg}$ dan ditambahkan $200 \mu \mathrm{L}$ PBS kemudian digerus hingga homogen. Semua homogenat dikoleksi, kemudian dimasukan pada tube steril. Homogenat disentrifuse $6000 \mathrm{rpm}$ selama 5 menit. Supernatan diambil dan dipindahkan ke dalam tube steril yang baru dan disimpan pada suhu $4^{\circ} \mathrm{C}$.

Supernatan yang didapat mengandung banyak protein, karena komposisi yang heterogen maka protein tersebut perlu dipisahkan untuk dilihat profilnya. Profil protein tanaman diamati untuk mengetahui apakah tanaman tersebut berhasil memproduksi protein yang berperan pada saat cekaman atau tidak. Media yang digunakan untuk memisahkan protein tersebut adalah gel SDS-PAGE yang terdiri dari stacking gel dan separating gel. Stacking gel SDS-PAGE yang dipisahkan memiliki konsentrasi 5\% (bagian atas) dan gardien gel atau separating gel SDS-
PAGE memiliki konsentrasi $10 \%$ (bagian bawah).

Setelah gel SDS-PAGE terbuat, maka larutan sampel dan marker dimasukan ke dalam sumuran pada gel tersebut dan akan di running. Sampel sebanyak $30 \mu \mathrm{L}$ ditambah bufer $10 \mu \mathrm{L}$, sehingga didapatkan volume akhir $40 \mu \mathrm{L}$. Hasil campuran tersebut kemudian dipanaskan pada air mendidih selama 2 menit, lalu dibekukan pada suhu $20^{\circ} \mathrm{C}$ selama 15 menit. Langkah selanjutnya adalah melakukan pengisian (loading) pada sumuran gel elektroforesis. Proses running dilakukan dengan menggunakan tenaga 125 volt selama 2 jam. Proses dihentikan apabila dari loading dye mendekati batas bawah dari lembaran gel polyacrylamida.

Proses elektroforesis selesai maka dilakukan pewarnaan terhadap hasil elektroforesis dengan coomasime blue $0,1 \%$ dengan dishaker selama 30 menit. Pada proses ini akan didapatkan hasil berupa lembaran gel berwarna biru. Setelah proses pewarnaan selesai maka dilakukan destaining untuk menghilangkan warna biru, namun pita-pita hasil running pada lembaran agar tetap dipertahankan berwarna biru.

\section{Rancangan Penelitian}

Rancangan penelitian yang digunakan adalah Rancangan Acak Lengkap (RAL) dengan 5 perlakuan dan 4 ulangan. Hasil dari parameter tinggi tanaman, panjang akar, berat kering, kandungan klorofil dan akumulasi $\mathrm{Pb}$ 
dalam akar akan dianalisis menggunakan ANOVA one way dengan taraf kepercayaan 95\%. Setelah itu dilakukan uji lanjutan dengan Uji Duncan Multiple Range Test (DMRT) untuk melihat pengaruh beda nyata tiap perlakuan.

\section{Hasil dan Pembahasan}

Pengaruh Pemberian Mikoriza Glomus sp. dan Logam Pb pada Tanaman Sengon (Paraserianthes falcataria $(\mathbf{L}$.$) Nielsen)$

Berdasarkan hasil uji ANOVA one-way dengan taraf kepercayaan 95\% diketahui bahwa inokulasi mikoriza berpengaruh nyata terhadap pertambahan tinggi dan kandungan klorofil, tetapi tidak berpengaruh nyata terhadap panjang akar berat kering. Untuk mengetahui adanya perbedaan pada parameter yang berbeda nyata tersebut dilakukan uji lanjutan DMRT (Tabel 1).

Parameter tinggi tanaman pada tabel 1 menunjukkan antara perlakuan kontrol negatif dan positif tidak berbeda nyata. tinggi tanaman pada perlakuan kontrol positif (dengan penambahan $\mathrm{Pb}$ ) lebih tinggi dibandingkan dengan kontrol negatif (tanpa penambahan $\mathrm{Pb}$ ). Hal ini karena akar tanaman yang terpapar logam $\mathrm{Pb}$ akan menjaga ion logam beracun dalam konsentrasi rendah dalam sitoplasma dengan mencegah transpor ion logam menembus membran plasma (Reichman, 2002). Pencegahan transport ion logam tersebut dengan cara meningkatkan pengikatan ion logam di dindng sel (Yang et al., 2005). Selain itu juga mengurangi penyerapan dengan memodifikasi ion channel yaitu suatu protein NRAMPS (natural resistance assosiation macrophage protein) sehingga terjadi efflux ion logam keluar sel (Tong et al., 2004) sehingga $\mathrm{Pb}$ tidak dapat mengganggu proses penyerapan hara dan pertumbuhan tinggi tanaman tidak terganggu.

Tabel 1. Pengaruh Inokulasi Glomus sp. terhadap Pertumbuhan Tanaman Sengon Tercekam Pb

\begin{tabular}{clccc}
\hline Perlakuan & $\begin{array}{l}\text { Pertambahan } \\
\text { tinggi } \\
\operatorname{tanaman}(\mathrm{cm})\end{array}$ & $\begin{array}{c}\text { Panjang } \\
\text { akar }(\mathrm{cm})\end{array}$ & $\begin{array}{c}\text { Berat } \\
\text { kering total }(\mathrm{gr})\end{array}$ & $\begin{array}{c}\text { Klorofil } \\
(\mathrm{gr} / \mathrm{ml})\end{array}$ \\
\hline P1 & $46,50 \pm 3,66 \mathrm{a}$ & 25,22 & 15,94 & $12,56 \mathrm{~d}$ \\
P2 & $52,38 \pm 2,58 \mathrm{ab}$ & 21,68 & 13,47 & $3,5 \mathrm{a}$ \\
P3 & $56,25 \pm 1,60 \mathrm{ab}$ & 31,35 & 16,28 & $4,27 \mathrm{a}$ \\
P4 & $61,75 \pm 1,18 \mathrm{~b}$ & 28,5 & 16,77 & $6,06 \mathrm{~b}$ \\
P5 & $77,50 \pm 5,00 \mathrm{~b}$ & 31,5 & 17,86 & $8,99 \mathrm{c}$ \\
\hline
\end{tabular}

Keterangan:Angka yang diikuti huruf yang sama pada kolom yang sama tidak berbeda nyata pada DMRT taraf $5 \%$. $\mathrm{P} 1$ = Tanpa mikoriza+Tanpa $\mathrm{Pb} ; \mathrm{P} 2=$ Tanpa mikoriza $+\mathrm{Pb} ; \mathrm{P} 3=$ Mikoriza 25gr $+\mathrm{Pb} ; \mathrm{P} 4=$ Mikoriza 50gr+Pb; $\mathrm{P} 5=$ 
Tinggi tanaman (tabel 1) pada perlakuan dengan penambahan dosis mikoriza lebih tinggi dibandingkan dengan kontrol negatif dan kontrol positif, dimana tinggi tanaman yang tertinggi pada pemberian dosis mikoriza 75 gram. Hal ini disebabkan fungi mikoriza efektif dalam meningkatkan penyerapan unsur hara makro dan mikro dengan memproduksi jalinan hifa yang intensif, ukuran hifa yang halus akan memungkinkan hifa bisa menembus pori - pori tanah yang paling kecil (mikro) sehingga bisa menyerap air pada kondisi kadar air yang sangat rendah serta membantu meningkatkan penyerapan unsur hara (Delvian, 2005).

Inokulasi mikoriza pada tanaman yang terpapar logam berat $\mathrm{Pb}$ juga mempengaruhi perkembangan panjang akar. Tabel 1 menunjukkan bahwa dengan penambahan mikoriza 25, 50 dan 75 gram, panjang akar mengalami peningkatan dibandingkan dengan kontrol. Hal ini karena mikoriza mampu menginduksi hipertrofi akar, sehingga mengakibatkan rangsangan tumbuhnya rambut-rambut akar menjadi lebih cepat. mikoriza juga mensekresikan hormon rizokalin lebih tinggi dibandingkan dengan yang tidak terinfeksi fungi mikoriza. Hormon rhizokalin berfungsi untuk merangsang pembentukan akar pada tanaman (Aldeman and Morton, 2006). Tabel 1 juga menunjukkan bahwa pada perlakuan kontrol positif (0 gram mikoriza +500 ppm $\left.\mathrm{Pb}\left(\mathrm{NO}_{3}\right)_{2}\right)$ memiliki panjang akar yang terendah. Hal ini karena logam $\mathrm{Pb}$ akan menghambat pertumbuhan dari akar primer (Obroucheva et al., 1998) dan perkembangan rambut akar (Sharma and Dubei, 2005) yaitu dengan menghambat pembelahan sel di zona meristematik akar dan pemanjangan sel akar primer (Ivanov et al., 1988).

Berat kering tanaman (tabel 1) juga mengalami peningkatan seiring dengan penambahan dosis mikoriza yaitu tertinggi pada pemberian dosis mikoriza75 gram. Berat kering juga berbanding lurus dengan pertumbuhan tinggi tanaman pada konsentrasi dosis mikoriza 75 gram serta infektivitas mikoriza pada akar tanaman sengon, hal ini karena pada infektivitas mikoriza terbentuk jalinan hifa yang berfungsi dalam pengambilan unsur hara dan air yang akan ditrisbusikan ke bagian batang dan daun sehingga meningkatkan laju proses fotosintesis. Berat kering tananam menggambarkan adanya akumulasi penyerapan bahan-bahan organik dan unsur hara yang dihasilkan saat fotosintesis (Desi dkk., 2013). Selain itu, tanaman sengon dengan perlakuan tanpa mikoriza dengan $\mathrm{Pb}$ (tabel 1) memiliki berat kering yang paling rendah. $\mathrm{Hal}$ ini karena $\mathrm{Pb}$ banyak mempengaruhi 
aktivitas metabolisme tanaman, diantaranya mengganggu fotosintesis dan penyerapan nutrisi atau unsur hara (Balba et al., 1991). Pb pada proses fotosintesis menghalangi transport elektron di reaksi terang dengan menghambat proses sintesis plastoquinon (PQ) dari plastoquinol $\left(\mathrm{PQH}_{2}\right), \mathrm{Pb}$ juga menghambat aktivitas enzim ferrodoxin $\mathrm{NADP}^{+}$reduktase sehingga menghalangi terbentuknya $\mathrm{NADP}^{+}$menjadi NADPH yang akan diteruskan dalam reaksi gelap (Tariq et al., 2007).

Glomus sp. yang menginfeksi sistem perakaraan tanaman sengon akan memproduksi jalinan hifa secara intensif, sehingga tanaman sengon bermikoriza akan mampu meningkatkan kapasitasnya dalam menyerap air dan unsur mineral. Ini sesuai dengan penelitian Sastrahidayat (2011) menyatakan bahwa infeksi mikoriza dapat membantu tanaman dalam menyediakan nutrisi yang diperlukan dalam pertumbuhan dan pemanjangan sel- sel batang. Infeksi mikoriza pada akar tanaman menyebabkan tanaman mampu memanfaatkan unsur-unsur $\mathrm{P}$ yang tidak tersedia menjadi tersedia (Rossiana dan Titin, 2003). Mikoriza meningkatkan penyerapan unsur $\mathrm{Mg}$ yang merupakan unsur utama dalam sintesis klorofil. Selain itu mikoriza juga mampu menginduksi zat perangsang tumbuh, seperti asam giberelat yang berperan dalam pembentukan klorofil (Peni dkk., 2004).

\section{Pengaruh Pemberian Mikoriza Glomus} sp. Terhadap Akumulasi Pb Pada Akar Tanaman Sengon (Paraserianthes falcataria (L.) Nielsen)

Berdasarkan uji Anova akumulasi logam $\mathrm{Pb}$ di akar menunjukkan hasil yang berpengaruh signifikan dengan nilai $p$. value 0,000 . Nilai $p$. value $<0,05$ menunjukkan hipotesa $\mathrm{H}_{0}$ ditolak, sehingga dilakukan uji lanjut Duncan (tabel 2.)

Tabel 2. Pengaruh pemberian mikoriza Glomus sp. terhadap Akumulasi Pb di akar tanaman sengon

\begin{tabular}{|l|c|}
\hline Perlakuan & $\begin{array}{c}\text { Akumulasi Pb di akar tanaman } \\
\text { sengon }(\mathrm{mg} / \mathrm{kg}) \pm \mathrm{SE}\end{array}$ \\
\hline 0 gr mikoriza-Pb & $0,13 \pm 0,05 \mathrm{a}$ \\
\hline 0 gr mikoriza+Pb & $1,16 \pm 0,35 \mathrm{ab}$ \\
\hline 25 gr mikoriza+Pb & $2,25 \pm 0,37 \mathrm{~b}$ \\
\hline 50 gr mikoriza+Pb & $3,49 \pm 0,15 \mathrm{c}$ \\
\hline 75 gr mikoriza+Pb & $3,60 \pm 0,60 \mathrm{c}$ \\
\hline
\end{tabular}

Keterangan : Huruf yang berbeda pada kolom menunjukkan pengaruh berbeda nyata pada uji Duncan $(\alpha=0,05 \%) \pm$ SE (standart eror) 
Hasil pada tabel diatas menunjukkan bahwa akumulasi $\mathrm{Pb}$ di akar dengan penambahan mikoriza berbeda nyata yaitu antara perlakuan kontrol negatif ( 0 gr mikoriza- $\mathrm{Pb})$ dan kontrol positif (0gr mikoriza+Pb) dengan perlakuan penambahan mikoriza dengan dosis 25, 50 dan 75 gram. Akumulasi $\mathrm{Pb}$ tertinggi pada perlakuan dosis mikoriza 75 gram dan akumulasi terendah pada perlakuan kontrol negatif (tanpa mikoriza tanpa $\mathrm{Pb}$ ). Hal ini sesuai dengan pernyataan Chen et al., (2007) bahwa penyerapan $\mathrm{Pb}$ pada akar tanaman bermikoriza lebih tinggi dibandingkan dengan non-mikoriza. Mikoriza diketahui mampu menyerap dan mengakumulasi logam dalam akar tanaman inang. Hifa miselium intra dan ekstraseluler MVA berpotensi dalam penyerapan logam (Joner et al., 2000) melalui luas permukaan penyerapan dan jangkauannya di dalam tanah. Sebagian besar logam terikat pada komponen dinding sel seperti kitin, selulose dan melanin fungi MVA (Galii et al., 1993). Suharno dan Sancayaningsih (2013) menyatakan bahwa Peningkatan masuknya $\mathrm{Pb}$ ke dalam akar tanaman umumnya diamati melalui kolonisasi mikoriza. Penyerapan $\mathrm{Pb}$ diketahui berkorelasi dengan meningkatnya jumlah infeksi MVA pada jenis tanaman yang terkolonisasi mikoriza.

\section{Uji Profil Protein}

Tanaman merespon hadirnya logam berat di lingkungan dengan berbagai cara, salah satunya dengan mensintesis protein fitokelatin yang merupakan hasil dari mekanisme pertahanan berupa metabolit sekunder yang berikatan dengan logam. Pada penelitian ini dilakukan pengujian profil protein terhadap tanaman sengon yang tumbuh pada lahan tercemar $\mathrm{Pb}$ dengan menggunakan metode SDS-PAGE.

Berdasarkan hasil uji profil protein (Gambar 1) menunjukan bahwa pita protein dengan berat molekul 53,67 kDa yang merupakan protein yang terbentuk pada saat tercekam $\mathrm{Pb}$. Berdasarkan hasil NCBI menunjukan bahwa protein yang terbentuk tersebut merupakan fitokelatin. Fitokhelatin merupakan peptida yang mengandung 2-8 asam amino sistein di pusat molekul serta suatu asam glutamat dan sebuah glisin pada ujung yang berlawanan. Fitokhelatin dibentuk di dalam nukleus yang kemudian melewati retikulum endoplasma (RE), aparatus golgi, vasikula sekretori untuk sampai ke permukaan sel. Bila bertemu dengan Timbal $(\mathrm{Pb})$ serta logam berat lainnya fitokhelatin akan membentuk ikatan 
sulfida di ujung belerang pada sistein dan membentuk senyawa kompleks sehingga Timbal $(\mathrm{Pb})$ dan logam berat lainnya akan terbawa menuju jaringan tumbuhan. Gangguan dapat terjadi pada jaringan epidermis, spons dan palisade (Taiz dan Zieger, 1998).

\footnotetext{
Gambar 1. Profil Protein Paraserianthes falcataria L. Keterangan : $\mathrm{K} 1=$ Tanpa mikoriza+Tanpa Pb; K2= Tanpa mikoriza $+\mathrm{Pb} ; \mathrm{M} 1=$ Mikoriza 25gr $+\mathrm{Pb} ; \mathrm{M} 2=$ Mikoriza 50gr $+\mathrm{Pb} ; \mathrm{M} 3=$ Mikoriza $75 \mathrm{gr}+\mathrm{Pb}$
}
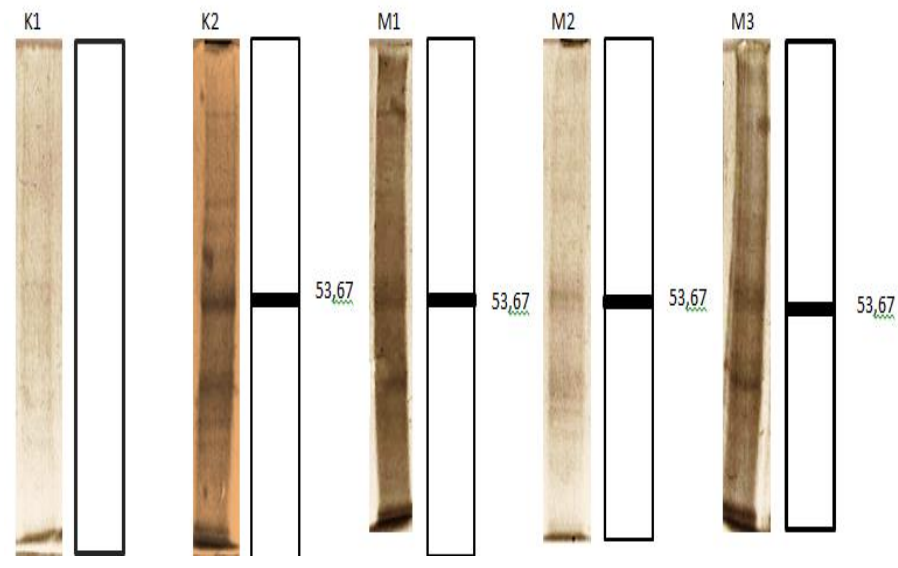

\section{Kesimpulan}

Berdasarkan hasil yang diperoleh, maka dapat disimpulkan bahwa pemberian beberapa dosis mikoriza Glomus sp. berpengaruh signifikan tehadap tinggi tanaman dan kandungan klorofil dalam media yang mengandung logam berat $\mathrm{Pb}$ dengan hasil tertinggi pada dosis mikoriza 75 gram, namun tidak berpengaruh signifikan pada panjang akar dan berat kering tanaman. Dan Pemberian beberapa dosis mikoriza dapat meningkatkan serapan $\mathrm{Pb}$ dan akumulasi logam $\mathrm{Pb}$ pada akar tanaman sengon. Serta hasil uji profil protein menunjukan tanaman sengon yang tumbuh pada lahan tercemar $\mathrm{Pb}$ terindentifikasi membentuk pita protein dengan berat molekul 53,67 kDA. 


\section{DAFTAR PUSTAKA}

Aldeman , J.M., and J.B. Morton. 2006. Infectivity of Vesicular Arbuscular Mychorrizal Fungi Influence Host Soil Diluent Combination on MPN Estimates and Percentage Colonization. Soil Biolchen Journal. Vol. 8 (1):77- 83.

Balba, A.M., Shibiny and Khatib. 1991. Effect of Lead Increments on the Yield and Lead Content of Tomato Plants, Water. Air Soil Pollut. Vol. 57 (93).

Chen, B., Zhu, Duan, Xiao X., and Smith S. 2007. Effects of the Arbuscular Mycorrhizal Fungus Glomus mosseae on Growth and Metal Uptake by Four Plant Species in Copper Mine Tailings. Environ Pollut. Vol. 147:374-380

Cunningham, S.D., and W.R. Berti. 1993. Remediation of Contaminated Soils with Green Plants: An Overview, In Vitro Cell. Dev. Biol. 29P:207-212.

Delvian. 2005. Pengaruh Cendawan Mikoriza Arbuskula Dan Naungan Terhadap Pertumbuhan Bibit Kayu Manis (Cinnamomum burmanii BL.). Jurnal Ilmiah Ilmu-Ilmu Pertanian Agrisol. Vol. 4 No.1.

Desi, L., R. Linda and Mukarlina. 2013. Pertumbuhan Jagung (Zea mays L.) dengan Pemberian Glomus aggregatum dan Biofertilizer pada Tanah Bekas Penambangan Emas. Jurnal Protobiont. Vol. 2 (3):176 - 180.

Etim, E.E. 2012. Phytoremediation and its Mechanisms: A Review. International Journal of Environmental and Bioenergy. Vol 2 (3):120-136

Galii, U., Meier M., and Brunold C. 1993. Effect of Cadmium on Nonmycorrhizal and Mycorrhizal Fungus (Laccasaria laccata Scop.Ex.Fr): Sulphate Reduction, Thiols and Distribution of the Heavy Metal. New Phytol. Vol. 125:837-843.

Hardiatmi, S.J.M. 2008. Pemanfaatan Jasad Renik Mikoriza untuk Memacu Pertumbuhan Tanaman Hutan. Jurnal Inovasi Pertanian. Vol.7 (1):1-10.

Ivanov, V.B., E.I. Bystrova, N.V. Obroucheva, O.V. Antipova, M. Sobotik and H. Bergmann. 1988. Growth Response of
Barley Roots as an Indicator of $\mathrm{Pb}$ Toxic Effects". J. Appl. Bot. Vol. 72 : 140-143.

Joner, E.J., Briones and Leyval C. 2000. MetalBinding Capacity of ArbuscularMycorrhizal Mycelium. Pl Soil. Vol. 226 (2):227-234.

Nouri , J., N. Khorasani, B. Lorestani, M. Karami, A.H. Hassani, N. Yousefi. 2009. Accumulation of Heavy Metals in Soil and Uptake by Plant Species with Phytoremediation Potential. Environ Earth Sci. Vol. 59:315-323.

Nugroho, T.A. dan Z. Salamah. 2015. Pengaruh Lama Perendaman dan Konsentrasi Biji Sengon (Paraserianthes falcataria L.). JUPEMASI-PBIO, Vol. 9 No. 3.

Nurhayati. 2012. Inffectiviness and Effectiviness of Mycorrhizae in the Some Host Plants and Source of Inoculum. Jurnal Agrista. Vol. 16 No. 2.

Obroucheva, N.V., V.B. Bystrova, O.V. Ivanov, M.S. Antipova and I.V. Seregin.1998. Root Growth Responses to Lead in Young Maize Seedlings. Plant Soil. Vol. 200:55-61.

Paivoke. 2002. Soil Lead Alters Phytase Activity and Mineral Nutrient Balance of Pisum sativum. Environ. Exp. Bot. 48:6173.

Peni, D.K., Solichatun dan E. Anggarawulan. 2004. Pertumbuhan, Kadar KlorofilKarotenoid, Saponin, Aktivitas Nitrat reduktase Anting-anting (Acalypha indica L.) pada Konsentrasi Asam Giberelat (GA3) yang Berbeda. Biofarmasi 2. Vol 1: $1-8$.

Reichman , S.M. 2002. The Responses of Plants to Metal Toxicity: A review focusing on Copper, Manganese and Zinc. Australian Minerals \& Energy Environment Foundation:Melbourne.

Rossiana, N. dan Titin S. 2003. Penurunan Kandungan Logam Berat dan Pertumbuhan Tanaman Senogon (Paraserianthes falcataria (L) Nielsen) Bermikoriza dalam Medium Limbah Lumpur Minyak Hasil Ekstraksi. UNPAD:Bandung. 
Saputro. T.B. 2012. Multiplikasi Tunas Pada Mikoropropagasi Tanaman Transgenik Anggrek (Phalaenopsis amabilis L.) Blume Pembawa 35S::KNAT1 Pada Media Tanpa Fitohormon. Thesis. UGM:Yogyakarta.

Sastrahidayat, I.R. 2011. Rekaya Pupuk Hayati Mikoriza dalam Meningkatkan Produksi Pertanian. Universitas Brawijaya Press : Malang.

Sergio, T., Pichardo, Yi Su and F. Han. 2012. The Potential Effects of Arbuscular Mycorrhizae (AM) on the Uptake of Heavy Metals by Plants from Contaminated Soils. J. Bioremediation \& Biodegradation. Vol. 3 (10).

Sharma, P., and S.R. Dubey. 2005. Lead Toxicity in Plants. Plant Physiol. Vol. 17 (1):3552.

Suharno and R.P. Sancayaningsih. 2013. Fungi Mikoriza Arbuskula: Potensi teknologi mikorizoremediasi logam berat dalam rehabilitasi lahan tambang. Bioteknologi. Vol. 10 (1):31-42

Suharti. 2008. Aplikasi Inokulum EM-4 dan Pengaruhnya Terhadap Pertumbuhan Bibit Sengon (Paraserianthes falcataria
(L.). Jurnal Penelitian Hutan dan Konservasi Alam. Vol. V no. 1.

Taiz, L. dan E. Zieger. 1998. Plant Physiology. Sinaver Associates. Inc. Publisher: Massachussets.

Tariq, M., K.R. Islam And S. Muhammad. 2007. Toxic Effects of Heavy Metals on Early Growth and Tolerance of Cereal Crops". Pakistan Journal of Botany. Vol.39 (2): 451-462.

Tong, Y.P., Kneer R., and Zhu Y.G. 2004. Vacuolar Compartementation : a Second Generation Approach to Engineering Plants for Phytoremediation. Trends Plants Science. Vol. 9:7-9.

Widyati. 2008. Peranan Mikroba Tanah pada Kegiatan Rehabilitasi Lahan Bekas Tambang (Roles of Soil Microbes in ExMining Land Rehabilitation). Info Hutan. Vol. 5 No. 2:151-160.

Yang, X., Feng Y., He Z., and Stoffella P.J. 2005. Molecular Mechanisms of Heavy Metal Hyperaccumulation and Phytoremediation. Journal of Trace Elements in Medicine and Biology. Vol. 18:339-53 